\title{
Anatomic Reconstruction of the Triangular Fibrocartilage Complex for the Treatment of Chronic Instability of the Distal Radioulnar Joint. A Systematic Review
}

\section{Reconstrucción anatómica del complejo fibrocartílago triangular para el tratamiento de la inestabilidad crónica de la articulación radiocubital distal. Una revisión sistemática}

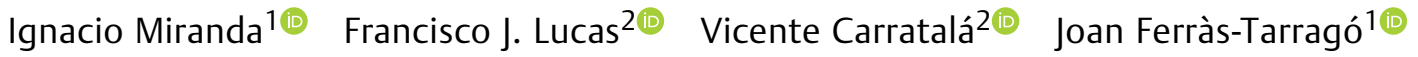 \\ Francisco J. Miranda ${ }^{3}$
}

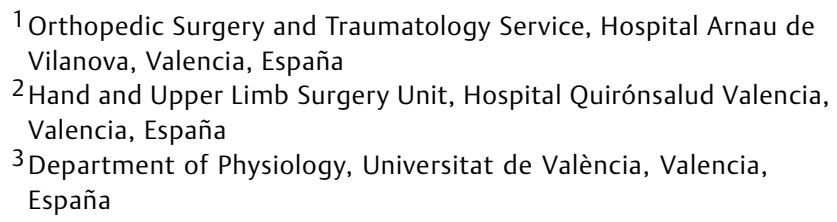

Address for correspondence Ignacio Miranda, MD, PhD, Servicio de Cirugía Ortopédica y Traumatología, Hospital Arnau de Vilanova, Calle Sant Climent 12, 46015 Valencia, España

(e-mail: nachomigo@hotmail.com).

Rev Iberam Cir Mano 2021;49(2):e97-e104.

\begin{abstract}
Keywords

- chronic distal radioulnar joint instability

- triangular fibrocartilage complex

- tendon plasty

- reconstruction of distal radioulnar ligaments

Introduction Peripheral injuries of the triangular fibrocartilage complex (TFCC) can produce pain and instability of the distal radioulnar joint (DRUJ). There are several techniques for the reconstruction of the TFCC. The aim of the present paper was to summarize the tendon plasties of the DRUJ ligaments for the anatomic reconstruction of TFCC, to analyze the surgical techniques, and to evaluate their outcomes.

Methods In order to perform a systematic review, we searched in the literature the terms DRUJ instability OR chronic distal radioulnar joint instability OR distal radioulnar tendon plasty.

Results In total, 11 articles with level of evidence IV (case series) were retrieved. Most studies achieved good results, with recovery of wrist stability, improvement of the pain, and increase in grip strength in the functionality tests. In the historical evolution of the published series, wrist surgeons tried to perform a more anatomical plasty, with a more stable fixation and less invasive techniques.
\end{abstract}

received

October 26, 2020

accepted

March 31, 2021
DOI https://doi.org/ 10.1055/s-0041-1736570. ISSN 1698-8396.

\footnotetext{
(c) 2021. SECMA Foundation. All rights reserved.

This is an open access article published by Thieme under the terms of the Creative Commons Attribution-NonDerivative-NonCommercial-License, permitting copying and reproduction so long as the original work is given appropriate credit. Contents may not be used for commercial purposes, or adapted, remixed, transformed or built upon. (https://creativecommons.org/ licenses/by-nc-nd/4.0/)

Thieme Revinter Publicações Ltda., Rua do Matoso 170, Rio de Janeiro, RJ, CEP 20270-135, Brazil
} 


\section{Resumen}

\author{
Palabras clave \\ - inestabilidad crónica \\ de la articulación \\ radiocubital distal \\ - complejo \\ fibrocartílago \\ triangular \\ - plastia tendinosa \\ - reconstrucción de \\ los ligamentos \\ radiocubitales \\ distales
}

Conclusion The Adams procedure continues to be a valid and reproducible technique for the treatment of chronic DRUJ instability. If wrist arthroscopy and implants are available and surgeons have been technically trained, the authors recommend an arthroscopy-assisted technique, or, if possible, an all-arthroscopic TFCC reconstruction with implant fixation of the plasty in its anatomical points of insertion. Comparative studies between open and arthroscopic TFCC reconstruction techniques are needed.

Introducción Las lesiones periféricas del complejo fibrocartílago triangular (CFCT) pueden provocar dolor e inestabilidad de la articulación radiocubital distal (ARCD). El objetivo de este trabajo fue recoger todas las plastias tendinosas de los ligamentos de la ARCD para la reconstrucción anatómica del CFCT, analizar las técnicas quirúrgicas, y evaluar sus resultados.

Métodos Para hacer una revisión sistemática, se realizó una búsqueda en inglés en la literatura con los términos DRUJ instability O chronic distal radioulnar joint instability $\mathrm{O}$ distal radioulnar tendon plasty.

Resultados Se encontraron once artículos de nivel de evidencia IV (series de casos). La mayoría de los trabajos consiguieron buenos resultados, con recuperación de la estabilidad de la muñeca, mejoría del dolor, y aumento de la fuerza de prensa en las pruebas de funcionalidad. En la evolución histórica de las series publicadas, los cirujanos de muñeca intentan realizar plastias cada vez más anatómicas, con una fijación más estable y con técnicas cada vez menos invasivas.

Conclusión El procedimiento de Adams continúa siendo una técnica válida y reproducible para el tratamiento de la inestabilidad crónica de la ARCD. Si la artroscopia de muñeca y los implantes están disponibles y los cirujanos están técnicamente capacitados, los autores recomiendan una técnica asistida por artroscopia o, si es posible, una técnica íntegramente artroscópica para la reconstrucción del CFCT, con una fijación con implantes de la plastia en sus puntos de inserción anatómicos. Son necesarios estudios comparativos entre la reconstrucción anatómica del CFCT mediante técnica abierta y artroscópica.

\section{Introduction}

The triangular fibrocartilage complex (TFCC) has two functional components, the distal component (dc) and the proximal component (pc). The dc-TFCC is formed by the ulnocarpal ligaments and the articular fibrocartilage, and its function is to support and contain the ulnar margin of the carpus (like a hammock). ${ }^{1}$ The pc-TFCC is composed of the volar and dorsal distal radioulnar ligaments, and it is the primary stabilizer of the distal radioulnar joint (DRUJ) during pronosupination of the forearm. The origin of the pc-TFCC is in the ulnar fovea rather than in the ulnar styloid, and it is attached to the most dorsal and volar limits of the sigmoid notch of the radius. ${ }^{1,2}$ The isometric area of the pc-TFCC is considered to be located in the ulnar fovea. ${ }^{1}$

In 1989, Palmer ${ }^{3}$ published a classification of TFCC injuries, and described 2 basic categories: class 1 , or traumatic injuries; and class 2 , or degenerative injuries. These categories were subdivided into types, depending on the location of the tear and the presence or absence of cartilage injury. ${ }^{3}$ Type 1-B injuries are traumatic tears of the ulnar periphery of the TFCC. When there is an isolated rupture of the dc-TFCC, DRUJ stability is preserved. However, when a type 1-B TFCC tear involves disruption of the pc-TFCC, the DRUJ becomes unstable. If the cartilage is well preserved, these type 1-B injuries with DRUJ instability are then classified as "Class 4: Nonrepairable peripheral TFCC tear", ${ }^{4,5}$ in the 5 -class treatmentoriented classification proposed by Atzei and Luchetti. ${ }^{5}$ Injury to the TFCC is a frequent cause of pain on the ulnar side and disability in the wrist; and if it is misdiagnosed or unsuccessfully treated, it may cause DRUJ chronic instability. $^{5}$

Reconstruction of the TFCC is indicated if the TFCC injury is not repairable, if there are no degenerative changes in the DRUJ (healthy articular cartilage), and if the interosseous membrane is functional (to rule out Essex-Lopresti injury). ${ }^{4,6}$ Numerous procedures have been described to restore the stability of the DRUJ through nonanatomic reconstructions. These techniques include extra-articular plasty, ${ }^{7,8}$ direct radioulnar fixation plasty to the joint, ${ }^{9-11}$ or dynamic muscular transfers using the pronator quadratus. ${ }^{12,13}$ These techniques are less effective than the anatomic reconstruction of the DRUJ ligaments using a tendon graft, which tries 
to reproduce the anatomy and biomechanics of the native TFCC. There are several tendon plasties for anatomic reconstruction of TFCC, which are difficult to be understood, differentiated, reproduced and compared.

The aim of this paper was to summarize the different tendon plasties of the DRUJ ligaments for the anatomic reconstruction of the TFCC, to analyze the surgical techniques, and to evaluate their outcomes.

\section{Methods}

A systematic literature review was performed in accordance with the Preferred Reporting Items for Systematic Reviews and Meta-Analyses (PRISMA) ${ }^{14}$ and the guidelines of the Quality of Reporting of Meta-analyses (QUOROM) group. ${ }^{15}$ On May 25th, 2020, a search in the PubMed and Cochrane Library databases was made with the terms distal radioulnar tendon plasty OR DRUJ instability OR chronic distal radioulnar joint instability. The database search resulted in a total of 356 articles, which were reviewed by 2 senior orthopedic surgeons. the references of the selected articles were also crosschecked (-Fig. 1).

Eligibility criteria: 1) articles which presented results of the treatment of DRUJ chronic instability with some kind of tendon plasty for TFCC anatomic reconstruction; and 2) full text available in English or Spanish.

Exclusion criteria: 1 ) review articles; 2) single-case-report articles; 3 ) letters to the editor or editorial comments; 4 ) book chapters; 5) Conference papers or posters; and 6) cadaveric studies.

The surgical techniques and outcomes described in the articles which fulfilled those criteria were analyzed.

\section{Results}

In total, 11 articles with level of evidence IV were retrieved. All of them presented case series (with 9 to 95 patients) of chronic DRUJ instability treated by an anatomic reconstruction using a tendon plasty. The previous papers ${ }^{16-18}$ described different types of open surgery reconstruction of the TFCC. In the last few years, case series of open surgery have been published, ${ }^{19,20}$ as well as arthroscopic reconstruction series of assisted open surgery. ${ }^{21,22}$ The surgical techniques are schematized in -Fig. $\mathbf{2}$ and summarized in - Table 1. The technique developed by Carratalá Baixauli et al. ${ }^{6}$ was excluded from this systematic review because, although it has already been published, only partial and preliminary results have been presented for 4 patients at 6 months. In this study, ${ }^{6}$ the score on the Visual Analog Scale (VAS) was of 1.75 (range: 0 to 4 ) after 6 months; the VAS score before the surgery was of 6.75 (range: 4 to 8 ). The score on the Quick Disabilities of the Arm, Shoulder and Hand (DASH) questionnaire before the surgery was of 44.70 (range: 36.25 to 54); after 6 months, it was of 11.18 (range: 6.75 to 18 ); the results on the Mayo Wrist Score after 6 months of follow-up were: excellent (95) in 1 case; good (90 and 85) in 2 cases; and fair (70) in 1 case.
Rejected: 308

- Different subject: 206

- Review article: 41

- Cadaveric studies: 27

- Single case report: 11

- Full text not available in English or

Spanish: 11

- Conference paper or poster: 2

- Duplicate: 2

- Letter to the editor or editorial comment: 1

Rejected: 38

- Different Subject: 27

- Surgical technique description without results: 8

- Preliminary results studies which where included in other studies as definitive results: 3
Research: Pubmed and Cochrane "distal radioulnar tendon plasty" OR "DRUJ instability" OR "chronic distal radioulnar joint instability" Articles for abstract review $(\mathrm{N}=356)$

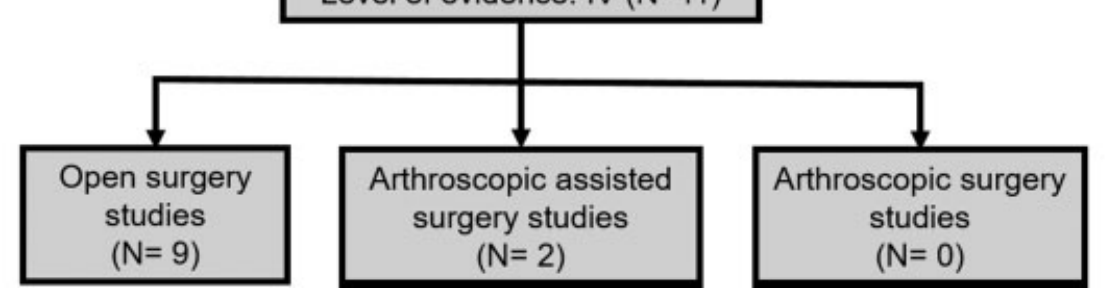

Fig. 1 Flowchart of the process of search and inclusion of studies. 


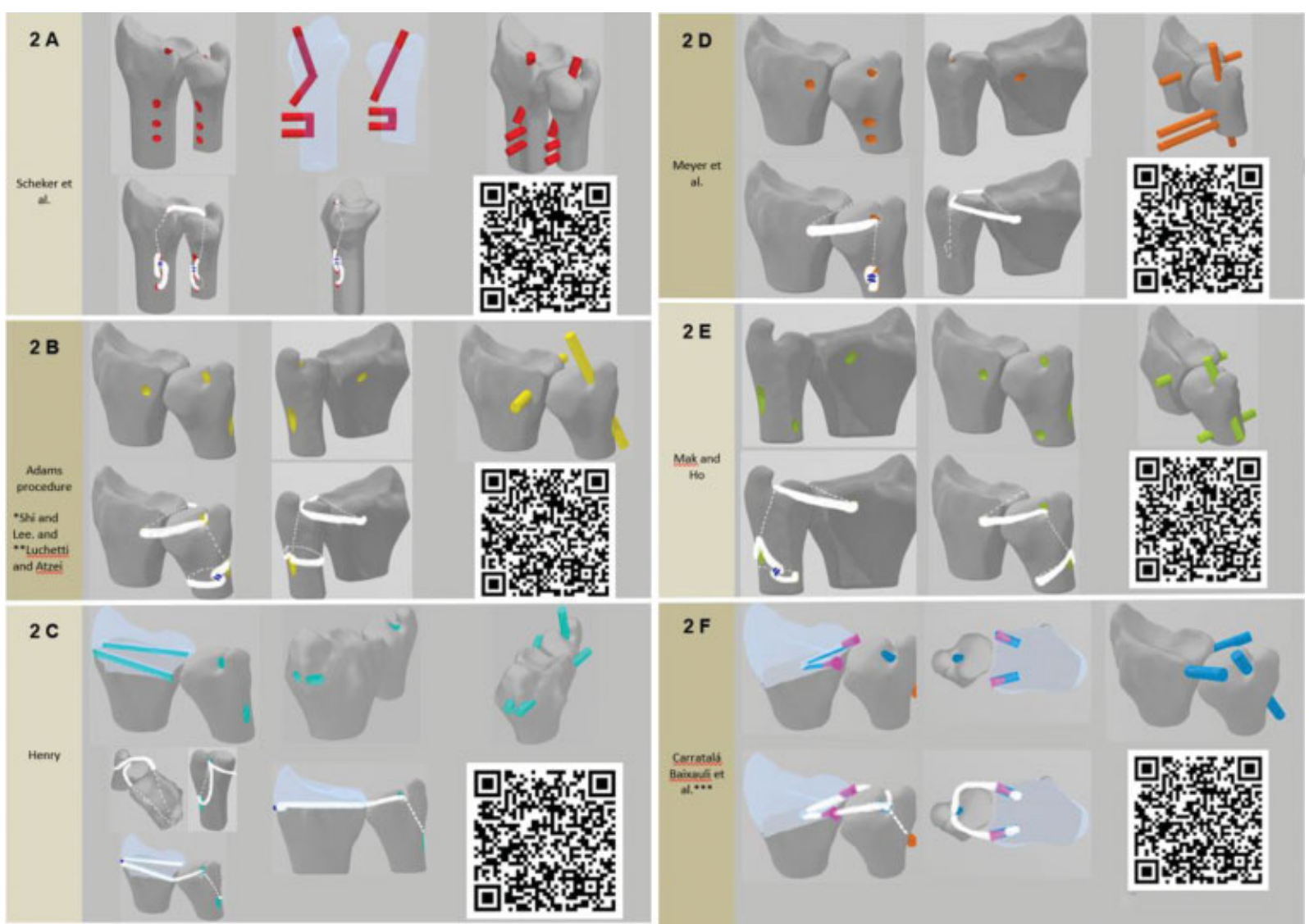

Fig. 2 Schemes of the TFCC reconstructions. The QR codes show the placement of the tunnels in 3D. (A). Scheker et al. ${ }^{16}$ technique. (B). Adams procedure. ${ }^{17-20,24 *}$ The Shih and Lee ${ }^{25}$ technique modifies the Adams procedure regarding the fixation of the plasty, which was sutured with polydioxanone suture (PDS) without an ulnar bundle. ${ }^{* *}$ The Luchetti and Atzei $^{22}$ technique modifies the Adams procedure regarding the fixation of the plasty, which is fixed in the ulna tunnel with an interference screw. (C) Henry ${ }^{27}$ technique. (D). Meyer et al. ${ }^{26}$ technique. (E) Chu-Kay Mak and $\mathrm{Ho}^{21}$ technique. (F). Carratalá Baixauli et al. ${ }^{6}$ technique. ${ }^{* * *}$ The Carratalá Baixauli et al. ${ }^{6}$ technique was excluded from the present systematic review because, although it has already been published, only partial and preliminary results have been presented for four patients at six months.

The outcomes were compiled: the pre- and postoperative ranges of motion (ROMs) are shown in - Table 2; the pain and grip strength, in - Table 3 ; and stability, functional scores and complications, in - Table 4.

\section{Discussion}

In total, 11 case series were retrieved, 9 with open surgery techniques ( 2 of them with previous diagnostic wrist arthroscopy), and 2 with arthroscopically-assisted procedures (-Table 1). In 1994, Scheker et al. ${ }^{16}$ published their series of 15 patients treated with a distal radioulnar plasty of the palmaris longus performed by open surgery; the authors reconstructed the dorsal distal radioulnar ligament ( - Fig. 2A), obtaining a disappearance of the pain in $80 \%$ of the patients, with increased strength and without losing mobility compared with the preoperative ROM. In 2000, Adams $^{23}$ described his technique for anatomic reconstruction of the dorsal and volar radioulnar ligaments with a palmaris longus autograft ( $\mathbf{F i g}$. 2B), and he published the results together with Berger in 2002. ${ }^{17}$ After that, four teams of surgeons performed the Adams procedure in their series, ${ }^{18-20,24}$ and most of the later-designed techniques retrieved in the present systematic review are modifications of this procedure, ${ }^{21,22,25,26}$ which is currently the gold-standard treatment for chronic DRUJ instability.

The 5 case series with reconstruction using the Adams technique (with 9, 14, 16, 74 and 95 patients) achieved good results in $86 \%$ to $100 \%$ of the patients, with recovery of wrist stability (78\% to $100 \%$ ), disappearance of the pain or mild pain $(76 \%$ to $89 \%)$ and increase in grip strength in the functionality tests. ${ }^{17-20,24}$ With this technique, most authors described a decrease in pronosupination compared with the preoperative ROM. ${ }^{17,19,20}$ Meyer et al. ${ }^{26}$ described a method of anatomic TFCC reconstruction which only differs from the Adams technique regarding the fixation of the ends of the tendon graft; it may enable a higher tension on the tendon graft and a more resistant fixation, thus enabling a less strict and shorter immobilization. They drilled two oblique tunnels in the ulna instead of the unique oblique tunnel in the Adams technique, and tied and secured the ends of the tendon graft over the bone bridge between the two drill holes $^{26}$ (-Fig. 2D); the outcomes were similar to those described with the Adams procedure.

In the series by Shih and Lee, ${ }^{25}$ all patients underwent wrist arthroscopic examination, and the lesions of the TFCC tears were identified, classified and, if indicated, a TFCC reconstruction was performed a week after with an extensor 
Table 1 Case series of tendon plasties of the DRUJ

\begin{tabular}{|c|c|c|c|c|c|}
\hline Authors & Year & $\mathrm{N}$ & Kind of Surgery & Graft & Tunnels and fixation \\
\hline Scheker et al. ${ }^{16}$ & 1994 & 15 & Open surgery & $\begin{array}{l}\text { Palmaris longus, } \\
\text { plantaris, or extensor } \\
\text { digitorum communis } \\
\text { autograft }\end{array}$ & $\begin{array}{l}3 \text { in the radius; } 3 \text { in the ulna; fixation } \\
\text { of the graft with } 2 \text { sutures over the } \\
\text { bone bridge (radius, ulna) }\end{array}$ \\
\hline Adams and Berger ${ }^{17}$ & 2002 & 14 & Open surgery & $\begin{array}{l}\text { Palmaris longus } \\
\text { autograft }\end{array}$ & $\begin{array}{l}\text { Posteroanterior in the radius; } \\
\text { oblique in the ulna; fixation of the } \\
\text { graft around the ulnar neck }\end{array}$ \\
\hline Teoh $\&$ Yam $^{18}$ & 2005 & 9 & Open surgery & $\begin{array}{l}\text { Palmaris longus } \\
\text { autograft }\end{array}$ & $\begin{array}{l}\text { Posteroanterior in the radius; } \\
\text { oblique in the ulna; fixation of the } \\
\text { graft around the ulnar neck }\end{array}$ \\
\hline Shih and $\operatorname{Lee}^{25}$ & 2005 & 37 & $\begin{array}{l}\text { Diagnostic } \\
\text { arthroscopy }+ \text { open } \\
\text { surgery ( } 1 \text { week after })\end{array}$ & $\begin{array}{l}\text { Extensor carpi ulnaris } \\
\text { autograft }\end{array}$ & $\begin{array}{l}\text { Posteroantrior in the radius; } \\
\text { oblique in the ulna }\end{array}$ \\
\hline Seo et al. ${ }^{24}$ & 2009 & 16 & Open surgery & $\begin{array}{l}\text { Palmaris longus } \\
\text { autograft }\end{array}$ & $\begin{array}{l}\text { Posteroanterior in the radius; } \\
\text { oblique in the ulna; fixation of the } \\
\text { graft around the ulnar neck }\end{array}$ \\
\hline Henry $^{27}$ & 2012 & 25 & $\begin{array}{l}\text { Diagnostic } \\
\text { arthroscopy }+ \text { open } \\
\text { surgery }\end{array}$ & $\begin{array}{l}\text { Palmaris longus } \\
\text { autograft }\end{array}$ & $\begin{array}{l}2 \text { in the sigmoid notch in the radius; } \\
\text { oblique in the ulna; suture over the } \\
\text { bone bridge (radius) }\end{array}$ \\
\hline Luchetti and Atzei ${ }^{22}$ & 2017 & 11 & $\begin{array}{l}\text { Arthroscopy-assisted } \\
\text { surgery }\end{array}$ & Palmaris longus & $\begin{array}{l}\text { Posteroanterior in the radius; } \\
\text { oblique in the ulna; linterference } \\
\text { screw in the ulna }\end{array}$ \\
\hline Meyer et al. ${ }^{26}$ & 2017 & 48 & Open surgery & $\begin{array}{l}\text { Palmaris longus, flexor } \\
\text { carpi ulnaris, or long } \\
\text { toe extensor autograft }\end{array}$ & $\begin{array}{l}\text { Posteroanterior in the radius; } \\
\text { oblique in the ulna; fixation of the } \\
\text { graft with suture over the bone } \\
\text { bridge (ulna) }\end{array}$ \\
\hline Chu-Kay Mak and $\mathrm{Ho}^{21}$ & 2017 & 28 & $\begin{array}{l}\text { Arthroscopy-assisted } \\
\text { surgery }\end{array}$ & $\begin{array}{l}\text { Palmaris longus } \\
\text { autograft }\end{array}$ & $\begin{array}{l}\text { Posteroanterior in the radius, } \\
\text { oblique in the } \\
\text { ulna; + posteroanterior in the ulna; } \\
\text { suture over the bone bridge (ulna) }\end{array}$ \\
\hline Kootstra et al. ${ }^{20}$ & 2018 & 22 & Open surgery & $\begin{array}{l}\text { Palmaris longus, toe } \\
\text { extensor, or plantaris } \\
\text { autograft }\end{array}$ & $\begin{array}{l}\text { Posteroanterior in the radius; } \\
\text { oblique in the ulna; Fixation of the } \\
\text { graft around the ulnar neck. }\end{array}$ \\
\hline Gillis et al. $^{19}$ & 2019 & 95 & Open surgery & $\begin{array}{l}\text { Autograft (44\%); } \\
\text { allograft (56\%). } \\
\text { Palmaris longus, } \\
\text { plantaris, triceps } \\
\text { surae, gracilis, or } \\
\text { semitendinosus }\end{array}$ & $\begin{array}{l}\text { Posteroanterior in the radius; } \\
\text { oblique in the ulna; fixation of the } \\
\text { graft around the ulnar neck, or } \\
\text { fixation with anchors or with } \\
\text { interference screw }\end{array}$ \\
\hline
\end{tabular}

carpi ulnaris (ECU) tendon graft with tunnels similar to those of the Adams procedure; despite the inconvenience of performing two surgeries, the outcomes were not better than those obtained with the Adams technique. Henry ${ }^{27}$ proposed a wrist arthroscopy, and, once the injury is confirmed, to proceed with open incisions and free tendon graft reconstruction with the palmaris longus; he replicated the true anatomic points of insertion both at the ulnar fovea and at the volar and dorsal margins of the sigmoid notch; the ends of the graft were tied to each other over the bone bridge of the radius (-Fig. $\mathbf{2 C}$ ). He reported restoration of the DRUJ stability in $100 \%$ of the cases, an improvement in the DASH score, and no decrease in ROM.

In the last few years, two series using arthroscopicallyassisted techniques were published. ${ }^{21,22}$ When compared with the open techniques for tendon-graft reconstruction, these techniques have some potential benefits: 1) visualization of the TFCC tear and assessment of reparability; 2) preservation of the capsule of the ulnar wrist and soft tissues; and 3) exposition of the fovea, which enables the surgeon to open the tunnel under direct view at the isometric insertion point of the fovea. Additionally, these techniques enable the surgeon to make smaller incisions to perform the reconstruction, thus minimizing soft-tissue scarring, fibrosis and stiffness. Luchetti and Atzei $^{22}$ performed the same tunnels as those of the Adams procedure, but fixed the graft in the ulna tunnel with an interference screw. Chu-Kay Mak and $\mathrm{Ho}^{21}$ (part of this series was previously published by Tse et al. ${ }^{28}$ ) performed the Adams technique, but made a second tunnel at the distal ulna, which is used to tie the ends of the graft to each other over the bone bridge of the ulna ( - Fig. 2E). The authors ${ }^{21}$ reported results comparable to those of the conventional open technique 
Table 2 Range of motion (ROM) outcomes

\begin{tabular}{|c|c|c|c|c|c|c|c|c|c|c|c|c|c|}
\hline \multirow[t]{2}{*}{ Authors } & \multicolumn{6}{|c|}{ Preoperative ROM (degrees) } & \multicolumn{6}{|c|}{ Postoperative ROM (degrees) } & \multirow{2}{*}{$\begin{array}{l}\text { Pre- vs. } \\
\text { postoperative }\end{array}$} \\
\hline & $\mathrm{F}$ & $\mathrm{E}$ & $\mathbf{P}$ & $\mathrm{s}$ & RD & UD & $\mathrm{F}$ & $\mathrm{E}$ & $\mathbf{P}$ & $S$ & RD & UD & \\
\hline Scheker et al. ${ }^{16}$ & 64 & 62 & 81 & 92 & 20 & 31 & 61 & 62 & 82 & 80 & 24 & 31 & $\downarrow S$ \\
\hline Adams and Berger ${ }^{17}$ & & & 80 & 80.5 & & & & & 72 & 70 & & & $\begin{array}{l}\downarrow S \text { and } P ; F \text {, } \\
\text { E and UD } \\
\text { unchanged }\end{array}$ \\
\hline Teoh and Yam ${ }^{18}$ & \multicolumn{6}{|c|}{ Nearly all patients with full S and P ROMs } & \multicolumn{6}{|c|}{ P-S (in \% of contralateral): $92 \%$} & \\
\hline \multicolumn{14}{|l|}{ Shih and $\mathrm{Lee}^{25}$} \\
\hline Seo et al. ${ }^{24}$ & 69.7 & 76.9 & 76.6 & 83.9 & 15 & 29.1 & 70.9 & 72.8 & 76.3 & 82.5 & 13.4 & 30.3 & No difference \\
\hline Henry ${ }^{27}$ & 53 & 53 & 66 & 65 & & & 61 & 62 & 71 & 74 & & & No difference \\
\hline Luchetti and Atzei ${ }^{22}$ & 64 & 70 & 85 & 81 & & & 60 & 67 & 80 & 81 & & & No difference \\
\hline Meyer et al. ${ }^{26}$ & 70.2 & 71.5 & 76.4 & 78.5 & 18.8 & 35.7 & 67.1 & 70.1 & 67.9 & 66.1 & 19.6 & 32.9 & $\downarrow \mathrm{S}$ and $\mathrm{P}$ \\
\hline $\begin{array}{l}\text { Chu-Kay Mak } \\
\text { and } \mathrm{Ho}^{21}\end{array}$ & \multicolumn{6}{|c|}{$\begin{array}{l}\text { In \% of contralateral: P-S: } 84.7 \% \text {; E-F: } \\
77.1 \% \text {; RD-UD: } 71.4 \%\end{array}$} & \multicolumn{6}{|c|}{$\begin{array}{l}\text { In \% of contralateral: P-S: } 91.1 \% \text {; E-F: } \\
\text { 83.7\%; RD-UD: } 83.5 \%\end{array}$} & Improved ROM \\
\hline Kootstra et al. ${ }^{20}$ & & & & & & & 67 & 71,8 & 73 & 71 & 17,7 & 30,9 & $\begin{array}{l}\downarrow \mathrm{S} \text { and } \mathrm{P} v \mathrm{vs} \\
\text { healthy wrist }\end{array}$ \\
\hline Gillis et al. ${ }^{19}$ & 53.9 & 57 & 76.9 & 69.7 & 18.3 & 27.2 & 52.1 & 58.6 & 71.3 & 62.7 & 19.8 & 28.6 & $\downarrow S$ and $P$ \\
\hline
\end{tabular}

Abbreviations: E, extension; F, flexion; P, pronation; RD, radial deviation;S, supination; UD, ulnar deviation; $\downarrow$, decrease.

Table 3 Pain and grip strength outcomes

\begin{tabular}{|c|c|c|c|c|c|c|c|}
\hline \multirow[t]{2}{*}{ Authors } & \multicolumn{3}{|l|}{ Preoperative } & \multicolumn{3}{|l|}{ Postoperative } & \multirow{2}{*}{$\begin{array}{l}\text { Pre- vs. } \\
\text { postoperative }\end{array}$} \\
\hline & Pain & $\begin{array}{l}\text { Grip } \\
\text { strength } \\
\text { (Kg) }\end{array}$ & $\begin{array}{l}\text { Grip strength } \\
\text { (\% contralateral } \\
\text { or healthy wrist) }\end{array}$ & Pain & $\begin{array}{l}\text { Grip } \\
\text { strength } \\
\text { (Kg) }\end{array}$ & $\begin{array}{l}\text { Grip Strength } \\
\text { (\%) contralateral } \\
\text { or healthy wrist) }\end{array}$ & \\
\hline Scheker et al. ${ }^{16}$ & $\begin{array}{l}100 \% \text { chief } \\
\text { complaint }\end{array}$ & 17 & 53.2 & $\begin{array}{l}86 \% \text { none; } 14 \% \\
\text { minor discomfort }\end{array}$ & 29.6 & 80.5 & $\begin{array}{l}\downarrow \text { pain; } \uparrow \text { grip } \\
\text { strength }\end{array}$ \\
\hline $\begin{array}{l}\text { Adams and } \\
\text { Berger }{ }^{17}\end{array}$ & & & & $64 \%$ none; $36 \%$ mild pain & $\begin{array}{l}\text { Improved } \\
11 \mathrm{~kg}\end{array}$ & 85 & $\uparrow$ grip strength \\
\hline Teoh and Yam ${ }^{18}$ & & & 55 & $66 \%$ mild pain & & 86 & $\uparrow$ grip strength \\
\hline Shih and $\mathrm{Lee}^{25}$ & & & 35 to 40 & $\begin{array}{l}\text { No patients with pain } \\
\text { in the daily activities }\end{array}$ & & 65 to 90 & $\uparrow$ grip strength \\
\hline Seo et al. ${ }^{24}$ & $\begin{array}{l}\text { PRWE (pain): } \\
23.1 / 50\end{array}$ & 31.6 & & PRWE (pain): 9.1/50 & 36.7 & & $\begin{array}{l}\downarrow \text { pain; } \uparrow \text { grip } \\
\text { strength }\end{array}$ \\
\hline Henry ${ }^{27}$ & & & 57 & & & 79 & No differences \\
\hline $\begin{array}{l}\text { Luchetti and } \\
\text { Atzei }^{22}\end{array}$ & $\begin{array}{l}\text { VAS (rest): } 4 ; \\
\text { VAS (stress): } 9\end{array}$ & 13 & 54 & $\begin{array}{l}\text { VAS (rest) } 2 \\
\text { VAS (stress) } 4\end{array}$ & 20 & 96 & $\begin{array}{l}\downarrow \text { pain; } \uparrow \text { grip } \\
\text { strength }\end{array}$ \\
\hline Meyer et al. ${ }^{26}$ & VAS: 2.6 & 24.6 & 63.9 & VAS: 1.3 & 31 & 80.3 & $\begin{array}{l}\downarrow \text { pain; } \uparrow \text { grip } \\
\text { strength }\end{array}$ \\
\hline $\begin{array}{l}\text { Chu-Kay Mak } \\
\text { and } \mathrm{Ho}^{21}\end{array}$ & VAS: 5.9 & & 58.6 & VAS: 3 & & 71.6 & $\begin{array}{l}\downarrow \text { pain; } \uparrow \text { grip } \\
\text { strength }\end{array}$ \\
\hline Kootstra et al. ${ }^{20}$ & & & & & 38.6 & 89.7 & \\
\hline Gillis et al. ${ }^{19}$ & $\begin{array}{l}33.7 \% \text { severe } \\
\text { pain; } 65.3 \% \\
\text { moderatepain; } \\
1.1 \% \text { mild pain }\end{array}$ & 21.7 & 68.5 & $\begin{array}{l}27.5 \% \text { no pain; } 48,4 \% \\
\text { mild pain; } 22 \% \\
\text { moderate pain }\end{array}$ & 24.2 & 77.4 & $\begin{array}{l}\downarrow \text { pain; } \uparrow \text { grip } \\
\text { strength }\end{array}$ \\
\hline
\end{tabular}

Abbreviations: PRWE, Patient-Rated Wrist Evaluation; VAS, Visual Analogue Scale; $\downarrow$, decrease; $\uparrow$, increase.

(stability, grip strength, and functionality); however, in addition to the cosmetic advantage, they achieved better ROM, through the preservation of soft-tissue and capsular integrity, and accelerated rehabilitation.
A new all-arthroscopic TFCC reconstruction technique has been described; ${ }^{6}$ however, it has been excluded from the present systematic review because the results have not been published yet . Carratalá Baixauli et al. ${ }^{6}$ performed a free 
Table 4 Stability, functional scores, complications and satisfaction outcomes

\begin{tabular}{|c|c|c|c|c|c|}
\hline \multirow[t]{2}{*}{ Authors } & \multirow{2}{*}{$\begin{array}{l}\text { Stability } \\
\text { (\% of patients) }\end{array}$} & \multicolumn{3}{|c|}{ Functional scores } & \multirow[t]{2}{*}{ Complications and satisfaction } \\
\hline & & Preoperative & Postoperative & $\begin{array}{l}\text { Pre- vs. } \\
\text { postoperative }\end{array}$ & \\
\hline Scheker et al. ${ }^{16}$ & & & & & $\begin{array}{l}1 \text { postblock brachial plexus neuritis; } \\
1 \text { mild reflex sympathetic dystrophy; } \\
1 \text { recurrence of instability }\end{array}$ \\
\hline Adams and Berger ${ }^{17}$ & 86 & & & & $\begin{array}{l}2 \text { recurrence of instability; } \\
2 \text { paraesthesia (healed) }\end{array}$ \\
\hline Teoh and Yam ${ }^{18}$ & 78 & MMWS: 66 & MMWS: 87 & Improvement & $\begin{array}{l}1 \text { paraesthesia (healed); } \\
1 \text { stiffness }\end{array}$ \\
\hline Shih and Lee ${ }^{25}$ & & & $\begin{array}{l}\text { MMWS: } \\
\text { 29.7\% excellent; } \\
59.5 \% \text { good; } \\
10.8 \% \text { fair }\end{array}$ & & 3 superficial wound infections \\
\hline Seo et al..$^{24}$ & 75 & $\begin{array}{l}\text { MMWS: } 72.5 \text {; } \\
\text { DASH: } 34.5 \text {; } \\
\text { PRWE: } 39.2\end{array}$ & $\begin{array}{l}\text { MMWS: } 92.8 ; \\
\text { DASH: } 10.5 ; \\
\text { PRWE: } 11.2\end{array}$ & Improvement & $\begin{array}{l}3 \text { laxity; } \\
1 \text { subluxation }\end{array}$ \\
\hline Henry $^{27}$ & 100 & DASH: 62 & DASH: 7 & Improvement & \\
\hline Luchetti and Atzei ${ }^{22}$ & 91 & $\begin{array}{l}\text { MWS: } 52 ; \\
\text { DASH: } 48 ; \\
\text { PRWE: } 70\end{array}$ & $\begin{array}{l}\text { MWS: } 82 ; \\
\text { DASH: } 25 ; \\
\text { PRWE: } 33\end{array}$ & Improvement & $\begin{array}{l}1 \text { fracture of the ulnar styloid (healed); } \\
3 \text { ulnar paraesthesia (healed); } \\
1 \text { graft rupture; } \\
1 \text { instability recurrence }\end{array}$ \\
\hline Meyer et al. ${ }^{26}$ & 91 & & & & $\begin{array}{l}2 \text { subluxation persisted; } \\
2 \text { recurrent instability }\end{array}$ \\
\hline Chu-Kay Mak and $\mathrm{Ho}^{21}$ & & MWS: 58 & MWS: 79 & Improvement & $\begin{array}{l}35,7 \%: \\
4 \text { graft rupture; } \\
3 \text { nerve injuries (healed); } \\
3 \text { discomfort over scar; } \\
1 \text { breakage KW }\end{array}$ \\
\hline Kootstra et al. ${ }^{20}$ & 100 & & $\begin{array}{l}\text { DASH: } 13.1 ; \\
\text { PRWHE: } 20.3\end{array}$ & & $4 \%$ recurrent instability \\
\hline Gillis et al. ${ }^{19}$ & 90.8 & MMWS 59.6 & MMWS 68.9 & Improvement & $\begin{array}{l}\text { 31.6\%: neuroapraxia, neuroma, } \\
\text { recurrent instability, degenerative disease; } \\
\text { satisfaction: VAS: } 8.1 \text { ( } 86.3 \%)\end{array}$ \\
\hline
\end{tabular}

Abbreviations: DASH, Disabilities of the Arm, Shoulder, Hand questionnaire; MMWS, Modified Mayo Wrist Score; MWS, Mayo Wrist Score; PRWE, Patient-Rated Wrist and Hand Evaluation Score; KW, kirschner wire.

tendon graft reconstruction, with the palmaris longus replicating the true anatomic points of insertion both at the ulnar fovea and at the volar and dorsal margins of the sigmoid notch, with two blind tunnels in the radius and an oblique ulnar tunnel; they fixed the graft with tree interference screws, two in the radius and one in the ulna ${ }^{6}$ (-Fig. 2F).

As shown in the historical evolution of the series herein presented, wrist surgeons tried to perform a more anatomical plasty, with a more stable fixation. With the introduction of arthroscopic techniques, smaller (and therefore more cosmetic) incisions, a more anatomical location of the tunnels, and lower soft-tissue damage have been achieved, thus enabling an improvement in ROM without worsening the results in terms of pain, stability, grip strength or functional scores.

The present review has some limitations, the main one being that all the studies retrieved have level IV of evidence (case series), but, to the best of our knowledge, no comparative studies or clinical trials have been published to date. In addition, in the case series analyzed, the authors used different items to measure the outcomes, and there was a lack of objective assessment of DRUJ instability.
In conclusion, the Adams procedure continues to be a valid and reproducible technique for the treatment of chronic DRUJ instability. If wrist arthroscopy and implants are available and surgeons are technically-trained, the authors recommend an arthroscopy-assisted technique, or, if possible, an all-arthroscopic TFCC reconstruction, with implant fixation of the plasty in its anatomical points of insertion. Comparative studies between open and arthroscopic TFCC reconstruction techniques are needed.

\section{Source of Funding}

The authors have no source of funding to declare.

Conflict of Interests

The authors have no conflict of interests to declare.

\section{References}

1 Nakamura T, Makita A. The proximal ligamentous component of the triangular fibrocartilage complex. J Hand Surg [Br] 2000;25 (05):479-486 
2 Nakamura T, Takayama S, Horiuchi Y, Yabe Y. Origins and insertions of the triangular fibrocartilage complex: a histological study. J Hand Surg [Br] 2001;26(05):446-454

3 Palmer AK. Triangular fibrocartilage complex lesions: a classification. J Hand Surg Am 1989;14(04):594-606. Doi: 10.1016/ 0363-5023(89)90174-3

4 Atzei A. New trends in arthroscopic management of type 1-B TFCC injuries with DRUJ instability. J Hand Surg Eur Vol 2009;34(05): 582-591

5 Atzei A, Luchetti R. Foveal TFCC tear classification and treatment. Hand Clin 2011;27(03):263-272. Doi: 10.1016/j.hcl.2011.05.014

6 Carratalá Baixauli V, Lucas García FJ, Martínez Andrade C, Carratalá Baixauli R, Guisasola Lerma E, Corella Montoya F. All-arthroscopic triangular fibrocartilage complex ligamentoplasty for chronic DRUJ instability. Tech Hand Up Extrem Surg 2019;23 (01):44-51. Doi: 10.1097/BTH.0000000000000222

7 Pürisa H, Sezer İ, Kabakaş F, Tunçer S, Ertürer E, Yazar M. Ligament reconstruction using the Fulkerson-Watson method to treat chronic isolated distal radioulnar joint instability: short-term results. Acta Orthop Traumatol Turc 2011;45(03):168-174. Doi: 10.3944/AOTT.2011.2380

8 Eliason EL. An operation for recurrent inferior radioulnar dislocation. Ann Surg 1932;96(01):27-35

9 Breen TF, Jupiter JB. Extensor carpi ulnaris and flexor carpi ulnaris tenodesis of the unstable distal ulna. J Hand Surg Am 1989;14 (04):612-617

10 Hui FC, Linscheid RL. Ulnotriquetral augmentation tenodesis: a reconstructive procedure for dorsal subluxation of the distal radioulnar joint. J Hand Surg Am 1982;7(03):230-236

11 El-Haj M, Baughman C, Thirkannad SM. A Technique for Treating Dorsal Instability of the Distal Radioulnar Joint. Tech Hand Up Extrem Surg 2017;21(02):67-70. Doi: 10.1097/ BTH.0000000000000157

12 Johnson RK, Shrewsbury MM. The pronator quadratus in motions and in stabilization of the radius and ulna at the distal radioulnar joint. J Hand Surg Am 1976;1(03):205-209

13 Lee SK, Lee JW, Choy WS. Volar Stabilization of the Distal Radioulnar Joint for Chronic Instability Using the Pronator Quadratus. Ann Plast Surg 2016;76(04):394-398. Doi: 10.1097/ SAP.0000000000000354

14 Liberati A, Altman DG, Tetzlaff J, et al. The PRISMA statement for reporting systematic reviews and meta-analyses of studies that evaluate health care interventions: explanation and elaboration. PLoS Med 2009;6(07):e1000100. Doi: 10.1371/journal. pmed. 1000100

15 Moher D, Cook DJ, Eastwood S, Olkin I, Rennie D, Stroup DFQUOROM Group. Improving the quality of reports of metaanalyses of randomised controlled trials: the QUOROM statement. Br J Surg 2000;87(11):1448-1454. Doi: 10.1046/j.13652168.2000.01610.x
16 Scheker LR, Belliappa PP, Acosta R, German DS. Reconstruction of the dorsal ligament of the triangular fibrocartilage complex. J Hand Surg [Br] 1994;19(03):310-318. Doi: 10.1016/0266-7681 (94)90079-5

17 Adams BD, Berger RA. An anatomic reconstruction of the distal radioulnar ligaments for posttraumatic distal radioulnar joint instability. J Hand Surg Am 2002;27(02):243-251. Doi: 10.1053/ jhsu.2002.31731

18 Teoh LC, Yam AKT. Anatomic reconstruction of the distal radioulnar ligaments: long-term results. J Hand Surg [Br] 2005;30(02): 185-193. Doi: 10.1016/j.jhsb.2004.10.017

19 Gillis JA, Soreide E, Khouri JS, Kadar A, Berger RA, Moran SL. Outcomes of the Adams-Berger Ligament Reconstruction for the Distal Radioulnar Joint Instability in 95 Consecutive Cases. J Wrist Surg 2019;8(04):268-275

20 Kootstra TJM, van Doesburg MH, Schuurman AH. Functional Effects of the Adams Procedure: A Retrospective Intervention Study. J Wrist Surg 2018;7(04):331-335. Doi: 10.1055/s-00381660812

21 Chu-Kay Mak M, Ho PC. Arthroscopic-Assisted Triangular Fibrocartilage Complex Reconstruction. Hand Clin 2017;33(04): 625-637. Doi: 10.1016/j.hcl.2017.07.014

22 Luchetti R, Atzei A. Arthroscopic assisted tendon reconstruction for triangular fibrocartilage complex irreparable tears. J Hand Surg Eur Vol 2017;42(04):346-351. Doi: 10.1177/ 1753193417690669

23 Adams BD. Anatomic Reconstruction of the Distal Radioulnar Ligaments for DRUJ Instability. Tech Hand Up Extrem Surg 2000;4 (03):154-160

24 Seo KN, Park MJ, Kang HJ. Anatomic reconstruction of the distal radioulnar ligament for posttraumatic distal radioulnar joint instability. Clin Orthop Surg 2009;1(03):138-145. Doi: 10.4055/ cios.2009.1.3.138

25 Shih JT, Lee HM. Functional results post-triangular fibrocartilage complex reconstruction with extensor carpi ulnaris with or without ulnar shortening in chronic distal radioulnar joint instability. Hand Surg 2005;10(2-3):169-176. Doi: 10.1142/ S0218810405002759

26 Meyer D, Schweizer A, Nagy L. Anatomic Reconstruction of Distal Radioulnar Ligaments With Tendon Graft for Treating Distal Radioulnar Joint Instability: Surgical Technique and Outcome. Tech Hand Up Extrem Surg 2017;21(03):107-113. Doi: 10.1097/ BTH.0000000000000163

27 Henry M. Anatomic reconstruction of the radioulnar ligament. Hand (N Y) 2012;7(04):413-419. Doi: 10.1007/s11552-0129456-7

28 Tse WL, Lau SW, Wong WY, et al. Arthroscopic reconstruction of triangular fibrocartilage complex (TFCC) with tendon graft for chronic DRUJ instability. Injury 2013;44(03):386-390. Doi: 10.1016/j.injury.2013.01.009 